Mizuki Wataya $\cdot$ Tetsuro Sano $\cdot$ Nobuhiro Kamikawaji

Takeshi Tana $\cdot$ Ken Yamamoto $\cdot$ Takehiko Sasazuki

\title{
Comparative analysis of HLA restriction and cytokine production in hepatitis $B$ surface antigen-specific $T$ cells from low- and high-antibody responders in vaccinated humans
}

Received: November 27, 2000 / Accepted: January 12, 2001

\begin{abstract}
It is well known that individuals with low, or lack of, antibody production in response to hepatitis B surface antigen (HBsAg) exist in the human population. We have previously reported that HLA class I and class II genes are both involved in antibody production to $\mathrm{HBs} \mathrm{Ag}$, and that specific alleles of HLA are associated with low and high antibody production. To elucidate further the mechanisms by which the diversity of antibody production to HBsAg is generated in humans, a total of $146 \mathrm{~T}$-cell clones specific for $\mathrm{HBsAg}$ were produced from six healthy vaccinees (three low- and three high-antibody responders) and were examined for cytokine production and HLA restriction. It was found that the majority of the T-cell clones from the lowantibody responders were Th1- or Th0-like T cells $(62 \%$ or $19 \%$, respectively), whereas the majority of T-cell clones from the high-antibody responders were Th2-like $\mathrm{T}$ cells (77\%), suggesting predominant expansion of Th1/Th0- and Th2-like T cells specific for HBsAg in the low- and highantibody responders, respectively. This is the first evidence that the diversity of the response to HBsAg in humans is controlled by the activation of functionally distinct $\mathrm{CD} 4^{+}$ T-cell subsets, i.e., Th0, Th1, or Th2 T cells.
\end{abstract}

M. Wataya $\cdot$ T. Sano ${ }^{1} \cdot$ N. Kamikawaji $\cdot$ T. Tana $\cdot$ K. Yamamoto $\cdot$ T. Sasazuki $(\bowtie)$

Department of Genetics, Medical Institute of Bioregulation, Kyushu University, 3-1-1 Maidashi, Higashi-ku, Fukuoka 812-8582, Japan

Tel. +81-92-642-6827; Fax +81-92-632-0150

e-mail: sasazuki@bioreg.kyushu-u.ac.jp

N. Kamikawaji

Department of Internal Medicine, South Fukuoka Hospital,

Fukuoka, Japan

T. Tana

The Third Department of Internal Medicine, Faculty of Medicine,

Ryukyu University, Okinawa, Japan

K. Yamamoto $\cdot$ T. Sasazuki

CREST, Japan Science and Technology Corporation, Fukuoka, Japan

Present address:

${ }^{1}$ Department of Cardiovascular Surgery, Faculty of Medicine,

Kyushu University, Fukuoka, Japan
Key words HLA - Polymorphism - Th0, Th1 and Th2 helper T cells $\cdot \mathrm{HBsAg} \cdot$ Immune regulation

\section{Introduction}

Hepatitis B virus infection is prevalent worldwide, and causes various types of clinical symptoms, including fulminant, acute, chronic active, and chronic persistent hepatitis; liver cirrhosis; and liver cancer; as well as producing an asymptomatic chronic carrier state. Vaccination with hepatitis B surface antigen (HBsAg) is performed worldwide, especially for hospital employees, because the neutralization of HBsAg by specific antibodies (Abs) is effective in preventing infection after accidental needle-stick exposure to HBsAg-positive blood (Hoofnagle et al. 1979; Itoh et al. 1986; Szmuness et al. 1980; Wainwright et al. 1989; Bocher et al. 1996). However, individual serum levels of HBsAgspecific $\mathrm{Ab}$ are diverse, and it has been reported that approximately $5 \%$ of vaccinees fail to produce the protective level of Abs to HBsAg after a standard vaccination schedule (Wismans et al. 1988).

We have previously reported that both HLA class I and class II genes are involved in the regulation of HBsAgspecific $\mathrm{Ab}$ production in the Japanese population (Mineta et al. 1996). HLA-DRB $1 * 08032$, DPA1*0103, DPB $1 * 0402$, DPB1*0202, and DPB1*1301 contribute positively to the anti-HBsAg antibody response, and HLA-A*2602, B70, DRB1*0405, DRB1*1101, and DQB1*0302 contribute negatively to the response. However, the combined correlation coefficient of the entire HLA gene family with HBsAgspecific $\mathrm{Ab}$ production is 0.50 by multiple regression analysis, indicating that not only the HLA multigene family but also other factor(s) significantly influence the immune response to $\mathrm{HBsAg}$. In addition, we also found that even low-Ab responders showed HBsAg-specific T-cell proliferation in vitro in many instances (Mineta et al. 1996; Min et al. 1996). These observations tempted us to investigate cellular mechanisms to determine the diversity of the $\mathrm{Ab}$ response to this $\mathrm{Ag}$ in humans. 
In the present study, we obtained peripheral blood mononuclear cells (PBMCs) from 92 vaccinees and analyzed the phenotypes after incubation of these cells with HBsAg in vitro, in terms of CD4, CD8, and CD56, and we investigated the association of Ab titer with these cell populations by flow cytometry. Because no specific change in cellular population was observed for low; or high-Ab responders by stimulation with HBsAg, we established a large number of HBsAg-specific T-cell clones from six healthy vaccinees (both low- and high-Ab responders), and we analyzed their cytokine production and determined HLA restriction. We report that $\mathrm{HBsAg}$-specific T-cell clones obtained from low-Ab responders showed $\mathrm{CD}_{4}^{+}$and Th1or Th0-like cytokine production, whereas those from high- $\mathrm{Ab}$ responders showed $\mathrm{CD} 4^{+}$and Th2-like cytokine production, providing evidence that the diversity of the $\mathrm{Ab}$ response to HBsAg in humans is regulated by the activation of functionally distinct $\mathrm{CD} 4^{+}$T-cell subsets, i.e., Th0, Th1, or Th2 $\mathrm{T}$ cells.

\section{Subjects and methods}

Vaccination and radioimmunoassay (RIA)

After informed consent was obtained from each subject, i.e., 92 healthy Japanese medical students, they were immunized subcutaneously with $20 \mu \mathrm{g}$ of recombinant (r)HBsAg vaccine (Derived Yeast, Chemo-Sero-Therapeutic Research Institute, Kumamoto, Japan) three times, at 0, 4, and 24 weeks, respectively. Peripheral blood was collected from each subject 2 months after the last vaccination for the measurement of serum antibody titer, $\mathrm{T}$-cell proliferation assay in vitro, and flow cytometry. Anti-HBsAg $\mathrm{Ab}$ titer was measured by RIA, using a commercial test system (Ausab; Abbott Laboratories, North Chicago, IL, USA).

For generating T-cell clones specific for HBsAg, six volunteers (three low- and three high-Ab responders, based on $\mathrm{Ab}$ titer), who had received their last vaccination 3 to 9 years ago, were revaccinated subcutaneously with $20 \mu \mathrm{g}$ of $\mathrm{HBsAg}$ vaccine. Peripheral blood was collected from each of these subjects before and 4 weeks after the revaccination for the measurement of serum antibody titer, T-cell proliferation assay in vitro, and flow cytometry.

\section{HLA typing}

DNA was extracted from peripheral granulocytes of each of the six volunteers (donors) by the standard sodiumdodecylsulfate (SDS)-proteinase $\mathrm{K}$ digestion/phenolchloroform extraction method. All subjects were genotyped for HLA class I (HLA-A) and class II (HLA-DRB1, DQA1, DQB1, DPA1, and DPB1) by the polymerase chain reaction (PCR)-single strand oligonucleotide probe (SSOP) method (Kimura et al. 1992; Date et al. 1996; Kimura and Sasazuki 1992). Briefly, $1 \mu \mathrm{g}$ of genomic DNA was amplified for HLA genes with primers designed to specifically amplify each HLA gene, by 30 cycles of PCR in a thermal cycler (Perkin Elmer Cetus, Norwalk, CT, USA) with Taq DNA polymerase (Takara Taq; Takara, Kyoto, Japan). PCR products were hybridized with ${ }^{32} \mathrm{P}$-labeled SSOP by dotblot hybridization. The HLA-B locus of HLA class I was serotyped using the microcytotoxicity test (Terasaki and McClelland 1964). The HLA DNA types of the six donors are shown in Table 1.

\section{Generation of T-cell clones}

The PBMCs from the fresh heparinized blood of each donor were separated by density gradient centrifugation, over Ficoll-Hypaque (Pharmacia, Uppsalia, Sweden). The PBMCs $\left(1 \times 10^{5}\right)$ were cultured in a 96-well roundbottomed plate (Corning, New York, NY, USA) with $10 \mu \mathrm{g} / \mathrm{ml}$ of recombinant HBsAg (rHBsAg) (Chemo-SeroTherapeutic Research Institute, Kumamoto, Japan) in $200 \mu \mathrm{l}$ of RPMI-1640 medium (Life Technologies, Grand Island, NY, USA), supplemented with $10 \%$ pooled human male serum, $2 \%$ l-glutamine (Life Technologies), and 1\% penicillin-streptomycin (Life Technologies)(termed complete medium), at $37^{\circ} \mathrm{C}$ in a humidified $5 \% \mathrm{CO} /$ air atmosphere. Viable cells were collected by density gradient centrifugation, and then $0.5 \times 10^{6}$ responding cells were restimulated with irradiated (30 Gy) $2.5 \times 10^{6}$ autologous PBMCs prepulsed with $40 \mu \mathrm{g} / \mathrm{ml}$ of rHBsAg (HBsAg-pulsed irradiated auto PBMCs) in the presence of $100 \mathrm{U} / \mathrm{ml}$ of recombinant interleukin-2 (rIL-2) (Ajinomoto, Kobe, Japan). After two additional stimulations, a single cell was picked up, under microscopy, from among the responding cells, for further cultivation with $5 \times 10^{4} \mathrm{HBsAg}$-pulsed irradiated auto PBMCs. T-cell clones were restimulated every week

Table 1. HLA types of six donors

\begin{tabular}{|c|c|c|c|c|c|c|c|}
\hline \multirow[b]{2}{*}{ Donor } & \multicolumn{7}{|l|}{ HLA type } \\
\hline & HLA-A & HLA-B & HLA-DRB1 & HLA-DQA1 & HLA-DQB1 & HLA-DPA1 & HLA-DPB1 \\
\hline Donor A & $0206 / 2401$ & $52 / 39$ & 0401/0901 & $0302 / 0302$ & 0301/03032 & 0103/0201 & 0201/0501 \\
\hline Donor B & 0201/0206 & $52 / 15$ & $1502 / 0901$ & 0103/0302 & 03032/06011 & 0201/02022 & 0901/0501 \\
\hline Donor C & 1101/0201 & $39 / 35$ & 0901/0901 & 0302/0302 & 03032/03032 & 0103/02022 & 0402/0501 \\
\hline Donor D & 0206/3101 & $51 / 7$ & 0101/0901 & 0302/0101 & 03032/0501 & 0103/02022 & 0201/0501 \\
\hline Donor E & $2402 / 2407$ & $62 / 35$ & 0405/0901 & $0302 / 0302$ & 03032/0401 & 0103/0201 & 0201/0901 \\
\hline Donor F & $0206 / 2402$ & $52 / 40$ & $1502 / 0901$ & 0103/0302 & 06011/03032 & 0103/0201 & 0201/0901 \\
\hline
\end{tabular}

HLA-A, DRB1, DQA1, DQB1, DPA1, and DPB1 were genotyped by the polymerase chain reaction (PCR)-single strand oligonucleotide probe (SSOP) method. HLA-B was serotyped by the microcytotoxicity test 
with HBsAg-pulsed irradiated auto PBMCs, four or five times, and then frozen until the assays were carried out.

\section{T-cell proliferation assay}

PBMCs $\left(1 \times 10^{5}\right.$ cells/well $)$ were incubated in a roundbottomed 96-well plate in $200 \mu \mathrm{l}$ of complete medium in the presence or absence of $5 \mu \mathrm{g} / \mathrm{ml} \mathrm{rHBsAg}$, or with $5 \mu \mathrm{g} / \mathrm{ml}$ purified protein derivatives (PPD) (Nihon BCG Seizo, Tokyo, Japan) for 1 week at $37^{\circ} \mathrm{C}$ in a humidified $5 \% \mathrm{CO} 2 /$ air atmosphere. Twelve $\mathrm{h}$ before being harvested, cells were pulsed with $1 \mu \mathrm{Ci}(6.7 \mathrm{Ci} / \mathrm{mmol})$ of $\left[{ }^{3} \mathrm{H}\right]$ thymidine (ICN Biomedicals, Costa Mesa, CA, USA). Subsequently, cells were collected onto glass fiber filters (Wallac, Turku, Finland), using an automatic cell collecter (Wallac), and the incorporated radioactivity was quantified with a liquid scintillation counter (Wallac). Results were expressed as mean counts per min $(\Delta \mathrm{cpm})$ in triplicate cultures. The value for the background proliferation in the absence of antigen was subtracted. The stimulation index (SI) was obtained by dividing the mean cpm with HBsAg stimulation by that without stimulation. To assess the proliferative response of T-cell clones to HBsAg, $1 \times 10^{4}$ cells of each clone were incubated with $1 \times 10^{5} \mathrm{HBsAg}$-pulsed or non-pulsed irradiated auto PBMCs in $200 \mu \mathrm{l}$ of complete medium, and proliferation was assayed by $\left[{ }^{3} \mathrm{H}\right]$ thymidine uptake, as described above. The SI was obtained by dividing the mean cpm to HBsAg-pulsed irradiated auto PBMCs by that to non-pulsed irradiated auto PBMCs.

\section{Flow cytometry and antibodies}

Cells $\left(1 \times 10^{4}-1 \times 10^{5}\right)$ were stained with fluorescein isothiocyanate (FITC) and phycoerythrin (PE)-conjugated or biotinylated monoclonal antibodies (MAbs) for $30 \mathrm{~min}$ at $4^{\circ} \mathrm{C}$ in phosphate-buffered saline (PBS) supplemented with $2 \%$ fetal calf serum (FCS) and $0.1 \%$ azide (FACS buffer). Then, the samples were washed three times with FACS buffer, resuspended, and analyzed on FACScan (Beckton Dickinson, San San Jose, CA, USA), using CellQuest software (Beckton Dickinson). The following MAbs were used for analysis: anti-CD4-PE or anti-CD4-biotin (Beckton Dickinson); anti-CD8-FITC or anti-CD8-biotin (Beckton Dickinson); anti-CD25-FITC (Pharmingen, San Diego, CA, USA) or anti-CD25-PE (Beckton Dickinson); anti-CD30FITC (Pharmingen), anti-CD95 (Fas)-biotin (Pharmingen), and anti-Fas Ligand-biotin (Pharmingen); and anti-CD56PE (Beckton Dickinson) and anti-TCR- $\alpha \beta$-FITC (Beckton Dickinson). Streptoavidin-R-PE (GIBCO BRL, Gaithersburg, MD, USA) was used to detect biotinylated reagents.

\section{HLA restriction of antigen recognition}

The HLA restriction of the HBsAg-specific T-cell clones was evaluated by adding MAbs against human HLA class II molecules or by using allogenic PBMCs (HLA matched or mismatched donors) as antigen-presenting cells (APCs) in the T-cell proliferation assay. The MAbs used were L243
(anti-HLA-DR), Leu 10 (anti-HLA-DP), and B7/21 (antiHLA-DQ). All were purchased from Beckton Dickinson. HBsAg-pulsed irradiated auto PBMCs $\left(1 \times 10^{5}\right.$ cells $)$ were incubated with MAbs for $1 \mathrm{~h}$ at $37^{\circ} \mathrm{C}$, and then T-cell clones $\left(1 \times 10^{4}\right.$ cells $)$ were added to the culture. In the experiment using allogenic PBMCs as APCs, $1 \times 10^{4} \mathrm{~T}$ cell clones were cultured with irradiated (30Gy) allogenic PBMCs prepulsed with $40 \mu \mathrm{g} / \mathrm{ml}$ of rHBsAg. All culture was carried out in $200 \mu \mathrm{l}$ of complete medium. Proliferation was assayed by $\left[{ }^{3} \mathrm{H}\right]$ thymidine incorporation, as described above.

\section{Enzyme-linked immunosorbent assay (ELISA)}

T-cell clones $\left(4 \times 10^{4}\right.$ cells $)$ were cultured with $1 \times 10^{5}$ HBsAg-pulsed or non-pulsed irradiated auto PBMCs, or with $1 \times 10^{5}$ irradiated auto PBMCs in the presence of $10 \mu \mathrm{g} / \mathrm{ml}$ p-phytohemayglutinin (PHA). After 24-h incubation, culture supernatants were collected and stored at $-80^{\circ} \mathrm{C}$. The concentrations of IL- 4 , interferon (IFN) $\gamma$, IL-2, and IL-10 in the supernatants were quantified by ELISA, using commercially available human cytokine kits (Endogen, Woburn, MA, USA).

\section{Results}

Antibody titers and phenotypes of PBMCs in 92 vaccinees

Four weeks after the final immunization with $\mathrm{HBsAg}$, serum and PBMCs of each subject were separated to examine the anti-HBsAg Ab titer, proliferative T-cell response to HBsAg, and the cellular population in PBMCs. Even low$\mathrm{Ab}$ responders showed a proliferative T-cell response to HBsAg (Fig. 1). The PBMCs were incubated with or without HBsAg in vitro and the phenotypes of the proliferated cells were analyzed by flow cytometry, using anti-CD4, antiCD8, and anti-CD56 MAbs. No clear correlation between $\mathrm{Ab}$ titer to HBsAg and the phenotype of the major population in PBMCs was observed, suggesting that the frequency of $\mathrm{T}$-cells involved in regulating $\mathrm{Ab}$ production was not large even in the vaccinated subjects.

Generation of T-cell clones specific for HBsAg from lowand high-Ab responders

For further analyses of $\mathrm{T}$ cells in low-Ab responders, three low- and three high-Ab responders were revaccinated with HBsAg, and T-cell clones specific for HBsAg were obtained from their PBMCs. Three donors described as low-Ab responders showed less than $36 \mathrm{mIU} / \mathrm{ml}$ of anti-HBsAg Ab both before and after revaccination (Fig. 2A; donors A, B, and $\mathrm{C}$ ). However, T-cell responses to $\mathrm{HBsAg}$ in vitro were observed in these donors (Fig. 2B; donors A, B, and C), indicating that the $I r$ gene defect hypothesis does not fit the mechanism of low-Ab response in these subjects. On the other hand, the three donors described as high-Ab responders showed between 52 and $602 \mathrm{mIU} / \mathrm{ml}$ of anti-HBsAg Ab before revaccination, and more than $7823 \mathrm{mIU} / \mathrm{ml}$ after 

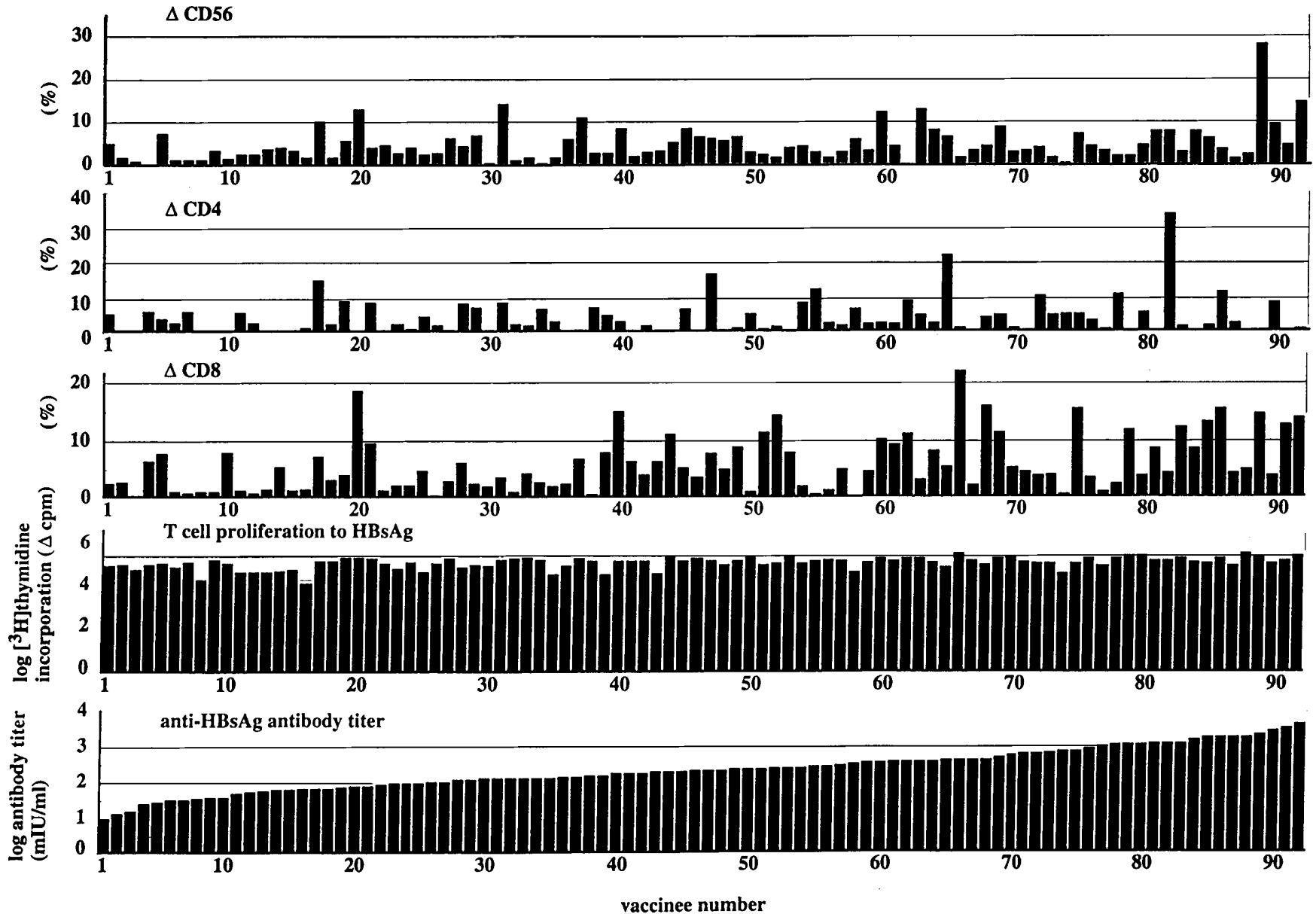

Fig. 1. Anti-hepatitis B surface antigen ( $H B s A g)$ antibody titer, proliferative $\mathrm{T}$-cell response, and phenotype change in peripheral blood mononuclear cells (PBMCs) by stimulation with $\mathrm{HBsAg}$ in vitro. Ninety-two healthy volunteers were vaccinated with recominant (r)HBsAg, and antibody and T-cell proliferative response to $\mathrm{HBsAg}$ were analyzed as described in the text. PBMCs of each subject were cultured in the presence or absence of rHBsAg and doubly stained with
anti-CD25 and the indicated antibody (Ab) (anti-CD56, anti-CD4, or anti-CD8). Only CD25-positive cells were analyzed for the expression of the indicated cell surface marker by flow cytometry. Data values presented (for $\Delta \mathrm{CD} 56, \Delta \mathrm{CD} 4$, and $\Delta \mathrm{CD} 8$ ) were calculated by subtracting the proportion of the indicated marker in the absence of $\mathrm{Ag}$ from that in the presence of $\mathrm{Ag}$

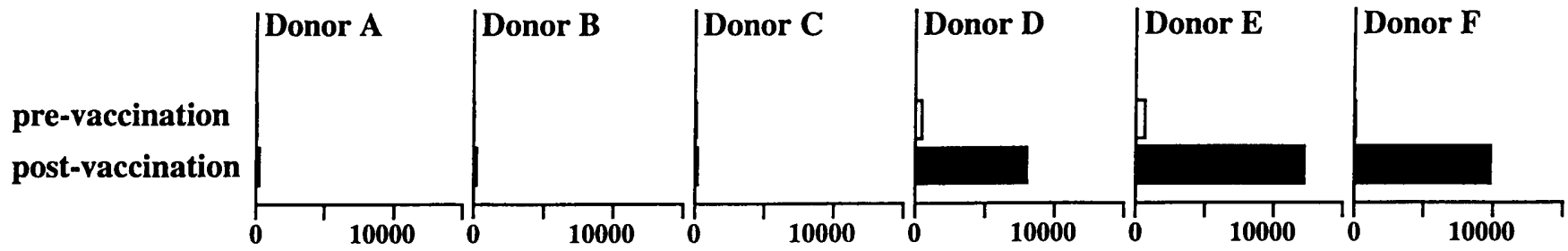

A

(mIU/ml)

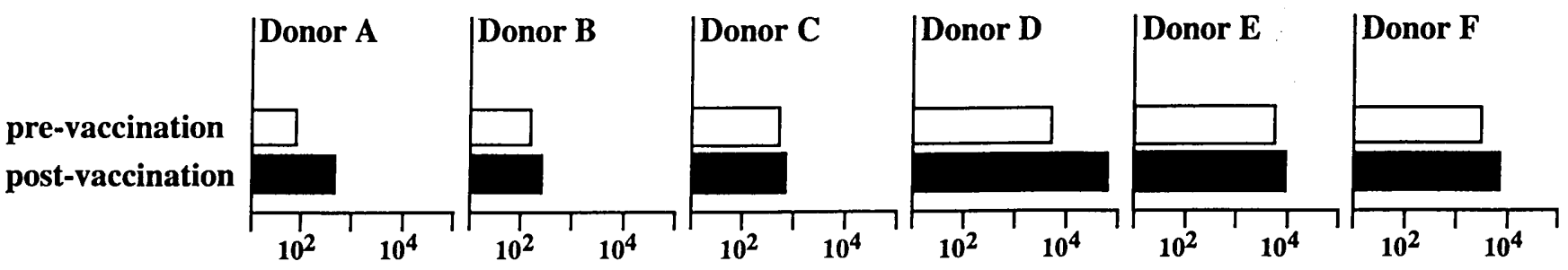

B

$\left[{ }^{3} \mathrm{H}\right]$ thymidine incorporation $(\Delta \mathrm{cpm})$

Fig. 2. A Anti-HBsAg antibody titer and $\mathbf{B}$ proliferative T-cell response in six subjects (three low-Ab responders [donors $\mathrm{A}, \mathrm{B}$, and $\mathrm{C}$ ] and three high-Ab responders [donors D, E, and F]). Open bars, Anti- body titer or T-cell proliferation pre-vaccination; solid bars, antibody titer or T-cell proliferation post-vaccination 
revaccination (Fig. 2A; donors D, E, and F). The T-cell phenotypes in PBMCs were analyzed by flow cytometry. However, no significant difference in the proportions of $\mathrm{CD}^{+}, \mathrm{CD}^{+}, \mathrm{CD} 25^{+}, \mathrm{FasL}^{+}$, or $\mathrm{CD} 30^{+} \mathrm{T}$ cells was observed between low- and high- $\mathrm{Ab}$ responders, even though cells were cultured with rHBsAg (data not shown).

A total of $146 \mathrm{HBsAg}$ specific T-cell clones were established. All clones showed proliferative responses to HBsAg (SI, $\geq 2.0$ ) and also to PHA (data not shown). To determine the phenotypes of these clones, they were subjected to flow cytometry, using anti-CD4, anti-CD8, anti-CD56, and anti$\mathrm{TCR} \alpha \beta$ Abs. All T-cell clones were $\mathrm{CD}^{2} 6^{-}, \mathrm{TCR} \alpha \beta^{+}$, and $\mathrm{CD}^{+}$, except for $16 \mathrm{CD}^{+}$T-cell clones obtained from donor B (data not shown), indicating that the major fraction of HBsAg-specific T cells is the conventional $\mathrm{CD} 4^{+} \mathrm{TCR} \alpha \beta$
$\mathrm{T}$ cell. The $\mathrm{CD} 8^{+} \mathrm{T}$-cell clones did not show cytotoxic activity to HBsAg-pulsed Epstein-Barr virus-transformed B cells (data not shown). Therefore, we focused on $\mathrm{CD} 4^{+} \mathrm{T}$ cell clones for further analyses.

Cytokine production of T-cell clones specific for HBsAg

All established $\mathrm{CD} 4^{+} \mathrm{T}$-cell clones were tested for cytokine production in terms of IL-2, IFN- $\gamma$, IL-4, and IL-10, by stimulation with HBsAg or PHA. The profiles of IL-4 and IFN- $\gamma$ production of all T-cell clones are presented in Fig. 3. Th1-like cells were defined as cells secreting less than $6 \mathrm{U} / \mathrm{ml}$ of IL-4 and more than $90 \mathrm{U} / \mathrm{ml}$ of IFN- $\gamma$ with $\mathrm{HBsAg}$ stimulation, and less than $26 \mathrm{U} / \mathrm{ml}$ of IL-4 and more than
Fig. 3A,B. Cytokine production profiles of T-cell clones obtained from six subjects. A total of 130 $\mathrm{T}$-cell clones were analyzed. Tcell clones were stimulated with A HBsAg and B phytohemaglutinin $(P H A)$ in vitro, and the concentrations of interleukin (IL)-4 and $\gamma$-interferon (IFN) in the supernatant were measured by enzyme-linked immunosorbent assays (ELISAs) as described in the text. Borderlines for defining Th cell type are indicated. Numbers in parentheses indicate the numbers of clones that showed the same levels of cytokine production

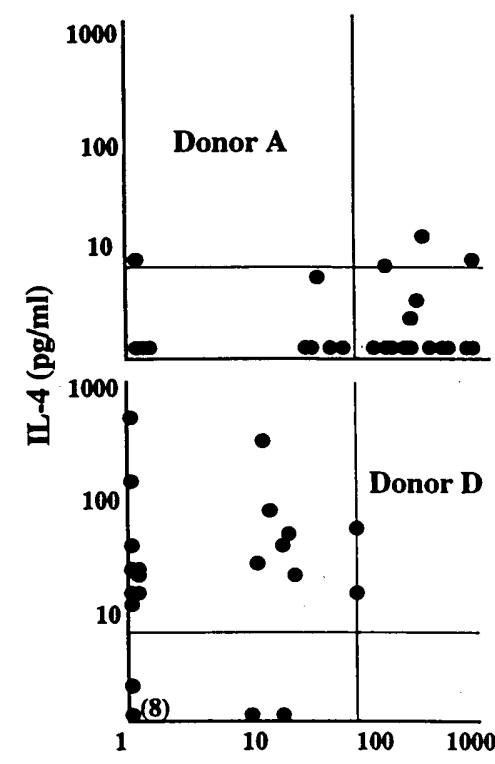

A

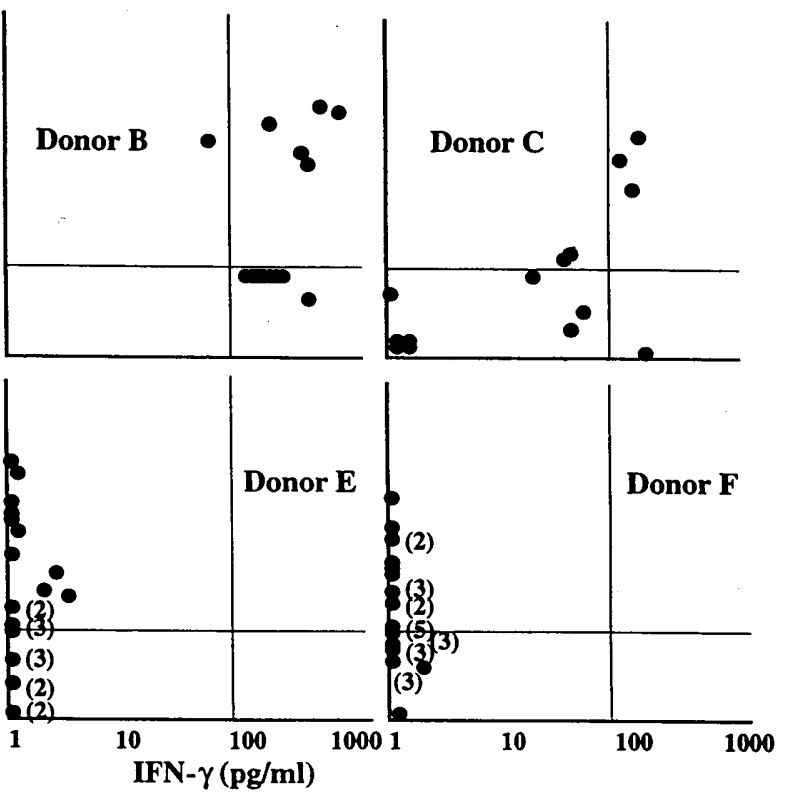

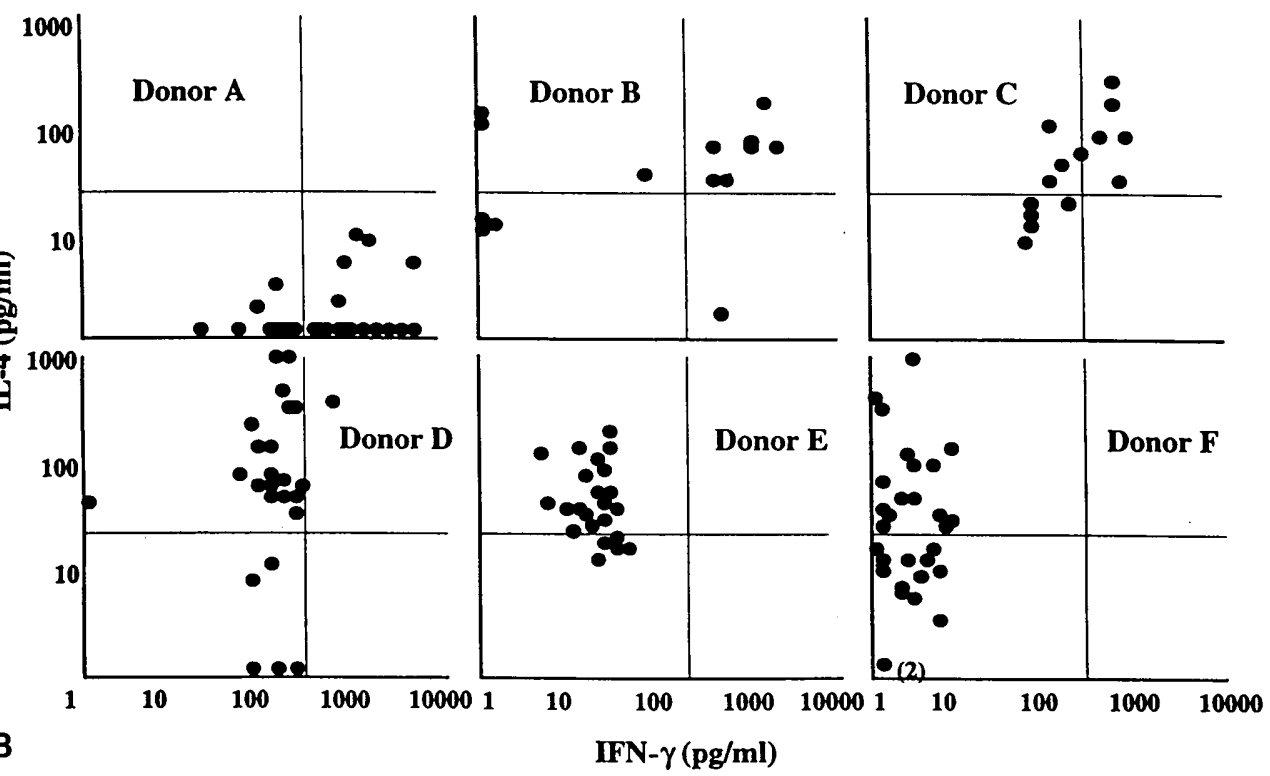

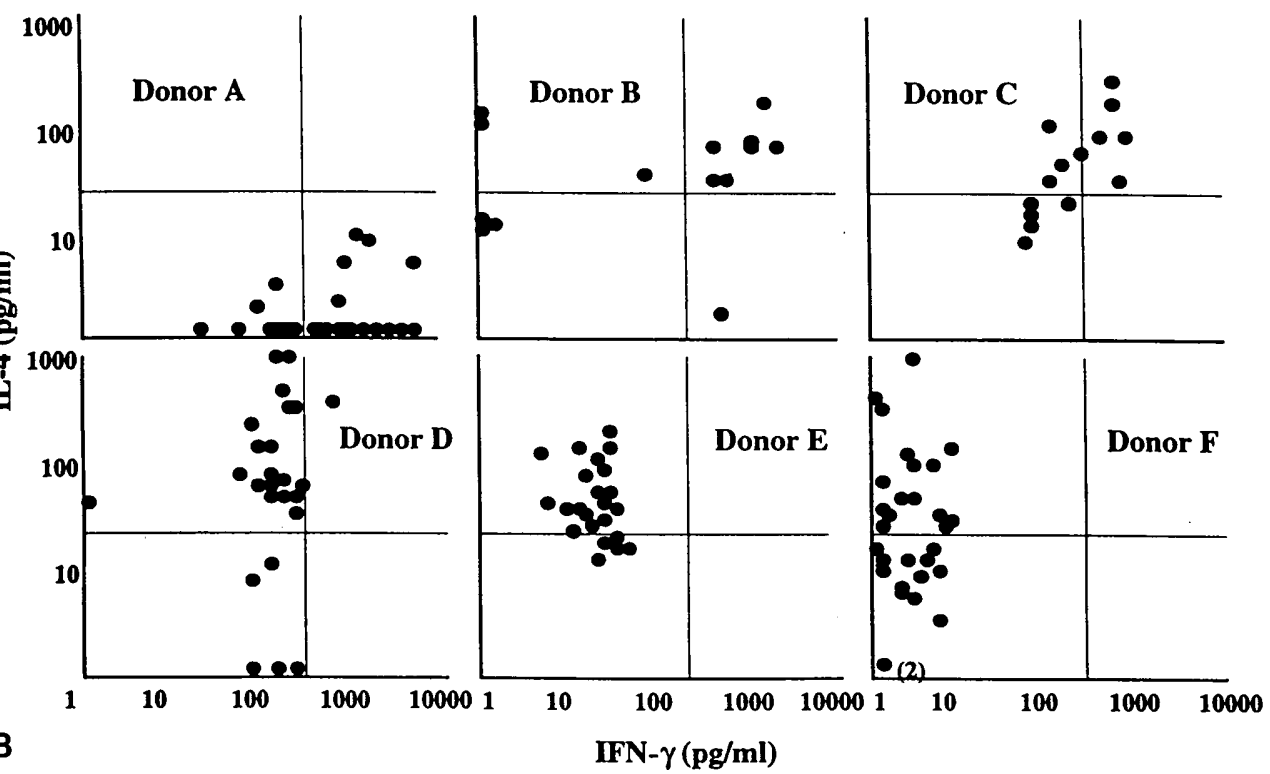


$344 \mathrm{U} / \mathrm{ml}$ of IFN- $\gamma$ with PHA stimulation. Th2-like cells were defined as cells secreting less than $90 \mathrm{U} / \mathrm{ml}$ of IFN- $\gamma$ and more than $6 \mathrm{U} / \mathrm{ml}$ of IL-4 with HBsAg stimulation, and less than $344 \mathrm{U} / \mathrm{ml}$ of IFN- $\gamma$ and more than $26 \mathrm{U} / \mathrm{ml}$ of IL-4 with PHA stimulation. Th0-like cells were defined as cells secreting more than $6 \mathrm{U} / \mathrm{ml}$ of IL-4 and $90 \mathrm{U} / \mathrm{ml}$ of IFN- $\gamma$ with HBsAg stimulation, and more than $26 \mathrm{U} / \mathrm{ml}$ of IL-4 and $344 \mathrm{U} / \mathrm{ml}$ of IFN- $\gamma$ with PHA stimulation. With this definition, it appeared that the majority of T-cell clones from low- $\mathrm{Ab}$ responders secreted large amounts of IFN- $\gamma$ or both IFN- $\gamma$ and IL-4, resembling Th1- or Th0-like T cells, respectively. Sixty-two percent (32/52) of the T-cell clones were Th1-like T cells, and 19\% (10/52) of the clones were Th0-like T cells, whereas the proportion of Th2-like T cells was only $8 \%(4 / 52)$. On the other hand, the majority of Tcell clones from high-Ab responders showed predominant secretion of IL-4. Seventy-seven percent (60/78) of the $\mathrm{T}$-cell clones were Th2-like T cells, whereas only 1 clone showed Th1- or Th0-like cytokine production. These results suggest predominant expansion of HBsAg-specific Th1- or Th0-like T cells in the PBMCs of low-Ab responders. On the other hand, the largest fraction of HBsAg-specific $T$ cells in the PBMCs of high-Ab responders was Th2-like $\mathrm{T}$ cells.

\section{HLA restriction of the T-cell clones specific for $\mathrm{HBsAg}$}

The HLA restriction of the $\mathrm{CD} 4^{+} \mathrm{T}$-cell clones was examined either by blocking experiments with MAbs (anti-DR $\mathrm{Ab}$, anti-DP $\mathrm{Ab}$, and anti-DQ $\mathrm{Ab}$ ) or by using HLA matched or mismatched allogenic PBMCs as APCs in proliferative assays. As shown in Table 2, in donor A, 19 clones were restricted to the DR molecule (DR4, DR9 or DR53) and 4 clones were restricted to the DP molecule (DP2). In donor F, 27 clones were restricted to the DR molecule (DR9 and DR15) and 2 clones were restricted to the DP molecule. This result indicated that HLA-DR was the major restriction molecule for T-cell clones from donors $\mathrm{A}$ and $\mathrm{F}$. The restriction molecules of the T-cell clones from the other donors were determined by the same method, and the results are summarized, together with findings on $\mathrm{T}$ helper subtypes, in Table 3. Based on our previous findings (Mineta et al. 1996), the HLA restriction of these T-cell clones was classified into four types; low-, high-, and neutral-HLA type restricted T-cells, and unknown type. Among the 52 clones from the low-Ab responders, 7 clones were low-HLA type restricted, 40 clones were neutral-HLA type restricted, and the restriction molecule of 5 clones was not known. On the other hand, among the 78 clones from the high- $\mathrm{Ab}$ responders, 17 clones were low-HLA type restricted, 59 clones were neutral-HLA type restricted, and the restriction molecule of 2 clones was not known.

\section{Discussion}

It is well known that there are individuals with low, or lack of, antibody production in the response to HBsAg in humans (Chiou et al. 1988; Varla-Leftherioti et al. 1990; Desombere et al. 1995; Egea et al. 1991; Kruskall et al. 1992; Watanabe et al. 1988; Hatae et al. 1992). The mechanisms of low responsiveness remain unclear, although several studies have revealed evidence relevant to the mechanisms. The absence of dominant immune response genes (Alper et al. 1989) or the presence of dominant immune suppression genes located in the MHC region (Watanabe et al. 1988; Hatae et al. 1992); defect of T-cell-APC interaction (Milich et al. 1984); selective killing of HBsAg-specific B cells by MHC-restricted cytotoxic T-lymphocytes (CTL) (Barnaba et al. 1990); imbalanced Th1/Th2 response to $\mathrm{HBsAg}$ (Vingerhoests et al. 1994; Hsu et al. 1996; Honorati et al. 1997; Bocher et al. 1999); and the elimination of HBsAgspecific $\mathrm{T}$ cells during thymic or postthymic repertoire maturation (Wismans et al. 1988) are mechanisms that have been proposed. Because the human population is largely outbred and carries varied HLA antigens, reflecting the marked polymorphism of the immune system, and because the population is exposed to diverse antigens, it is not easy to simply uncover the mechanisms of non/low responsiveness.

In our present study, the level of T-cell response in low$\mathrm{Ab}$ responders was lower than that in the high-Ab responders. This may be explained by the absence of Ir genes, by a defect of T-cell-APC interaction, and/or by the elimination of $\mathrm{HBsAg}$-specific $\mathrm{T}$ cells during repertoire selection in the low-Ab responders. However, T-cell responses specific for HBsAg observed in the low-Ab responders were significant, indicating that other mechanisms than those mentioned above exist and generate low-Ab responsiveness.

It has been demonstrated that CTL selectively killed HBsAg-specific B cells (Barnaba et al. 1990, and, accordingly, we examined a possible correlation between the level of $\mathrm{Ab}$ specific for HBsAg and the proportion of $\mathrm{CD} 8^{+} \mathrm{T}$ cells in PBMCs incubated with $\mathrm{HBsAg}$ in vitro. Because no specific increase in the population of $\mathrm{CD}^{+}$cells was observed in low-Ab responders and because the majority of HBsAg-specific T-cell clones from low-Ab responders were $\mathrm{CD}^{+}$, we dare to conclude that $\mathrm{CD} 8^{+} \mathrm{T}$ cells do not have critical roles in low-Ab responsiveness to $\mathrm{HBs} A g$, at least in the subjects analyzed.

The immune systems have been characterized as having two distinct types of helper T cells, Th1 and Th2 (Mosmann et al. 1986; Wierenga et al. 1991; reviewed in Romagnani 1991). The hallmark cytokine of Th1 cells is IFN- $\gamma$, and Th1 cells also produce IL-2, tumor necrosis factor (TNF), and leukotriene (LT), cytokines that mediate delayed-type hypersensitivity responses and macrophage activation. The signature cytokine of Th2 cells is IL-4, and Th2 cells also secrete IL-5, IL-9, IL-10, and IL-13, cytokines that provide help to B cells and are critical in the allergic response (Arthur and Mason 1986; Paliard et al. 1988; reviewed in Mosmann and Coffman 1989; reviewed in Paul and Seder 1994). Because of small sample sizes and/or differences in subjects (i.e., healthy volunteers or hepatitis patients), it has been unclear whether the skewing of the immune response toward Th1 or Th2 is involved in the regulation of Ab production to HBsAg in humans. In the present study, 
Table 2. Restriction molecules of T-cell clones obtained from donor A and donor F

\begin{tabular}{|c|c|c|c|c|c|c|}
\hline \multirow{3}{*}{$\begin{array}{l}\text { Donor A } \\
\text { Clone }\end{array}$} & \multicolumn{5}{|c|}{ Proliferative response $(\Delta \mathrm{cpm})^{\mathrm{a}}[\%]^{\mathrm{b}}$} & \multirow[b]{3}{*}{ Restriction molecule } \\
\hline & \multicolumn{2}{|c|}{ Allo $^{\mathrm{d}}$ PBMCs used as APCs } & \multicolumn{3}{|c|}{ Antibodies used for blocking } & \\
\hline & Allo $1^{\mathrm{c}}$ & Allo $2^{\mathrm{c}}$ & Anti-DR & Anti-DP & Anti-DQ & \\
\hline 1 & $9,559[22.2]$ & $27,651[64.2]$ & $345[0.8]$ & $6,060[14.1]$ & 38,615 [89.7] & DR53 \\
\hline 2 & $2,580[41.8]$ & $397[6.4]$ & $2,365[38.3]$ & $1,381[22.4]$ & $2,537[41.1]$ & DP2 \\
\hline 3 & $15,142[93.5]$ & $195[1.2]$ & $8,980[55.4]$ & $1,853[11.4]$ & $1,920[11.9]$ & DQ3/DP2 \\
\hline 4 & $578[4.1]$ & $1,458[10.2]$ & $10,012[70.4]$ & $1,552[10.9]$ & $13,319[93.6]$ & DP5 \\
\hline 5 & $9,570[62.2]$ & $1,130[7.3]$ & $174[1.1]$ & $2,790[18.1]$ & $7,222[47.0]$ & DR9 \\
\hline 6 & $58,407[74.2]$ & $168[0.2]$ & $25,155[31.9]$ & $8,665[11.0]$ & $65,780[83.5]$ & DP2 \\
\hline 7 & $5,262[6.9]$ & $41,606[54.8]$ & $467[0.6]$ & $16,588[21.8]$ & $57,389[75.6]$ & DR4 \\
\hline 8 & $12,753[48.2]$ & $12,049[45.6]$ & $3,789[14.3]$ & $7,848[29.7]$ & $23,380[88.4]$ & DR53 \\
\hline 9 & $4,921[7.0]$ & $39,491[56.1]$ & $10,784[15.3]$ & $6,571[9.3]$ & $47,537[67.6]$ & DP \\
\hline 10 & $30,581[455]$ & $62,949[93.6]$ & $33,675[50.1]$ & $21,964[32.7]$ & $65,366[97.2]$ & DR53 \\
\hline 11 & $51,757[83.6]$ & $358[0.6]$ & $38,171[61.6]$ & $26,141[42.2]$ & $60,753[98.1]$ & DR9 \\
\hline 12 & 31,054 [101.1] & $139[0.5]$ & $13,054[42.5]$ & $23,508[76.6]$ & $25,579[83.3]$ & DR9 \\
\hline 13 & $39,610[83.6]$ & $134[0.3]$ & $128[0.3]$ & $33,163[70.0]$ & $31,788[67.1]$ & DR9 \\
\hline 14 & $32,126[55.1]$ & $327[0.6]$ & $307[0.5]$ & $40,337[69.2]$ & $62,380[107.1]$ & DR9 \\
\hline 15 & $28,537[39.3]$ & $46,513[64.1]$ & $287[0.4]$ & $35,290[48.6]$ & 68,151 [93.9] & DR53 \\
\hline 16 & $12,019[52.6]$ & $223[1.0]$ & $131[0.6]$ & 4,851 [21.2] & $20,234[88.6]$ & DR9 \\
\hline 17 & $142[0.3]$ & $24,155[47.9]$ & $118[0.2]$ & $17,100[33.9]$ & $43,190[85.6]$ & DR4 \\
\hline 18 & $30,902[44.2]$ & $57,460[82.2]$ & $1,065[1.5]$ & $28,395[40.6]$ & $56,240[80.5]$ & DR53 \\
\hline 19 & 1,355 [29.2] & $3,490[75.3]$ & 115 [2.5] & $2,022[43.6]$ & $2,425[52.3]$ & DR4 \\
\hline 20 & $11,322[38.4]$ & 26,901 [91.2] & $332[1.1]$ & $27,539[93.4]$ & $38,568[130.9]$ & DR53 \\
\hline 21 & $35,738[50.2]$ & $54,722[76.8]$ & $1,906[2.7]$ & $63,356[88.9]$ & $82,302[115.6]$ & DR53 \\
\hline 22 & $8,053[17.6]$ & $35,429[77.4]$ & $370[0.8]$ & $27,425[59.9]$ & $46,322[101.2]$ & DR4 \\
\hline 23 & $290[0.5]$ & $39,205[68.7]$ & $152[0.3]$ & $14,771[25.9]$ & $32,919[57.7]$ & DR4 \\
\hline 24 & $431[5.6]$ & $1,186[15.6]$ & $135[1.8]$ & $1,534[20.2]$ & $9,482[124.4]$ & DR4 \\
\hline
\end{tabular}

\section{Donor F}

\begin{tabular}{|c|c|c|c|c|c|c|}
\hline Clone & Allo $3^{\mathrm{c}}$ & Allo $4^{\mathrm{c}}$ & Anti-DR & Anti-DP & Anti-DQ & Restriction molecule \\
\hline 1 & $28,280[74.3]$ & $141[0.4]$ & $9,025[23.7]$ & $21,104[55.4]$ & 40,343 [105.9] & DR9 \\
\hline 2 & 24,743 [44.7] & $42[0.1]$ & $16,807[30.4]$ & $26,303[47.5]$ & 24,342 [44.0] & DR9 \\
\hline 3 & $26,117[185.1]$ & $175[1.2]$ & 2,905 [20.6] & $6,392[45.3]$ & $10,370[73.5]$ & DR9 \\
\hline 4 & $16,276[82.8]$ & $217[1.1]$ & $3,659[18.6]$ & $10,500[53.4]$ & $15,732[80.0]$ & DR9 \\
\hline 5 & 4,464 [107.1] & 69 [1.7] & $180[4.3]$ & 968 [23.2] & $3,141[75.3]$ & DR9 \\
\hline 6 & $24,671[91.6]$ & $237[0.9]$ & $7,941[29.5]$ & $15,679[58.2]$ & 18,231 [67.7] & DR9 \\
\hline 7 & 538 [6.6] & 315 [3.9] & $6,981[86.0]$ & $363[4.5]$ & $7,220[88.9]$ & DP \\
\hline 8 & $383[10.5]$ & $13,167[361.3]$ & $115[3.2]$ & $1,030[28.3]$ & $2,561[70.3]$ & DR15 \\
\hline 9 & $123[0.2]$ & $18,340[33.4]$ & $2,849[5.2]$ & $26,404[48.1]$ & $34,687[68.2]$ & DR15 \\
\hline 10 & 171 [1.6] & $653[6.2]$ & $2,674[25.4]$ & $142[1.4]$ & 3,988 [37.9] & DP \\
\hline 11 & 3,237 [139.9] & $4[0.2]$ & $2,213[95.6]$ & $553[23.9]$ & $1,771[76.5]$ & DR9 \\
\hline 12 & $14,633[127.0]$ & $210[1.8]$ & $2,213[19.2]$ & 7,102 [61.7] & $13,151[114.2]$ & DR9 \\
\hline 13 & $5,836[144.6]$ & $21[0.5]$ & $342[8.5]$ & $1,700[42.1]$ & 4,739 [117.4] & DR9 \\
\hline 14 & $22,347[247.4]$ & 173 [1.9] & $956[10.6]$ & $5,591[61.9]$ & $9,041[100.1]$ & DR9 \\
\hline 15 & $32,825[163.3]$ & $92[0.5]$ & $2,545[12.7]$ & $10,845[54.0]$ & $17,000[84.6]$ & DR9 \\
\hline 16 & $42,511[280.8]$ & $114[0.8]$ & $3,337[22.0]$ & $6,647[43.9]$ & $13,300[87.9]$ & DR9 \\
\hline 17 & $14,104[268.1]$ & $260[4.9]$ & $825[15.7]$ & $2,999[57.0]$ & $5,674[107.9]$ & DR9 \\
\hline 18 & $14,762[378.3]$ & $179[4.6]$ & $548[14.0]$ & $1,139[29.2]$ & $3,581[91.8]$ & DR9 \\
\hline 19 & 18,224 [204.9] & $233[2.6]$ & 788 [8.9] & $4,484[50.4]$ & $8,393[94.3]$ & DR9 \\
\hline 20 & $49,122[202.3]$ & $245[1.0]$ & $3,632[15.0]$ & $19,320[79.6]$ & 27,019 [111.3] & DR9 \\
\hline 21 & $19,363[234.0]$ & $320[3.9]$ & $865[10.5]$ & $4,033[48.7]$ & $6,560[79.3]$ & DR9 \\
\hline 22 & $12,351[564.5]$ & 194 [8.9] & 190 [8.7] & $1,148[52.5]$ & $1,848[84.5]$ & DR9 \\
\hline 23 & $6,482[252.4]$ & $185[7.2]$ & $575[22.4]$ & $1,034[40.3]$ & $2,288[89.1]$ & DR9 \\
\hline 24 & $53,396[343.2]$ & $230[1.5]$ & $3,401[21.9]$ & $8,097[52.1]$ & 14,714 [94.6] & DR9 \\
\hline 25 & $16,111[174.1]$ & $219[2.4]$ & $2,514[27.2]$ & $5,660[61.2]$ & $15,774[170.4]$ & DR9 \\
\hline 26 & $35,809[180.2]$ & $173[0.9]$ & $2,147[10.8]$ & $9,630[48.4]$ & $19,298[97.1]$ & DR9 \\
\hline 27 & $5,881[124.6]$ & $1,276[27.0]$ & $1,467[31.1]$ & $2,874[60.9]$ & $5,477[116.1]$ & DR9 \\
\hline 28 & $3,680[239.1]$ & 163 [10.6] & $350[22.7]$ & $776[50.4]$ & $1,000[65.0]$ & DR9 \\
\hline 29 & $44,893[372.3]$ & $142[1.2]$ & $4,973[41.2]$ & $10,784[89.4]$ & $16,857[140.0]$ & DR9 \\
\hline
\end{tabular}

${ }^{\mathrm{a}} \Delta \mathrm{cpm}$ was calculated by subtracting the count in the absence of hepatitis B surface antigen (HBsAg) from that in the presence of Ag in the experiment using allo peripheral blood mononuclear cells (PBMCs) as antigen-presenting cells (APCs). In the blocking experiment, $\Delta$ cpm was calculated by subtracting the count in the presence of blocking antibody ( $\mathrm{Ab}$ ) from that in the absence of $\mathrm{Ab}$ in the condition with $\mathrm{HBs} \mathrm{Ag}$

${ }^{b}$ Percent response in the experiment using allo PBMCs as APCs was calculated by dividing the $\Delta \mathrm{cpm}$, shown in this table, by that using auto PBMCs as APCs. Percent response in the blocking experiment was calculated by dividing $\Delta \mathrm{cpm}$, shown in this table, by $\Delta$ cpm calculated by subtracting the count in the absence of HBsAg from that in the presence of $\mathrm{Ag}$ in the condition without blocking $\mathrm{Ab}$

${ }^{c}$ The DNA types of HLA class II of allo PBMCs are: allo 1, HLA-DRB1*0405/0901, -DQA1*0302/0302, -DQB1*03032/0401, -DPA1*0103/0103, -DPB1*0201/0402; allo 2, HLA-DRB1*0401/1101, -DQB1*0301/0301, -DPB1*1401/1401 (DPA1 and DQA1 are not genotyped); allo 3, HLADRB1*0405/0901, -DQA1*0302/0302, -DQB1*0401/03032, -DPA1*0103/0103, -DPB1*0201/0402; allo 4, HLA-DRB1*1101/1502, -DQA1*0103/ 05013, -DQB1*0301/06011, -DPA1*02022/0201, -DPB1*0901/1401

"For explanation of the terms "allo" and "auto" PBMCs, see text 


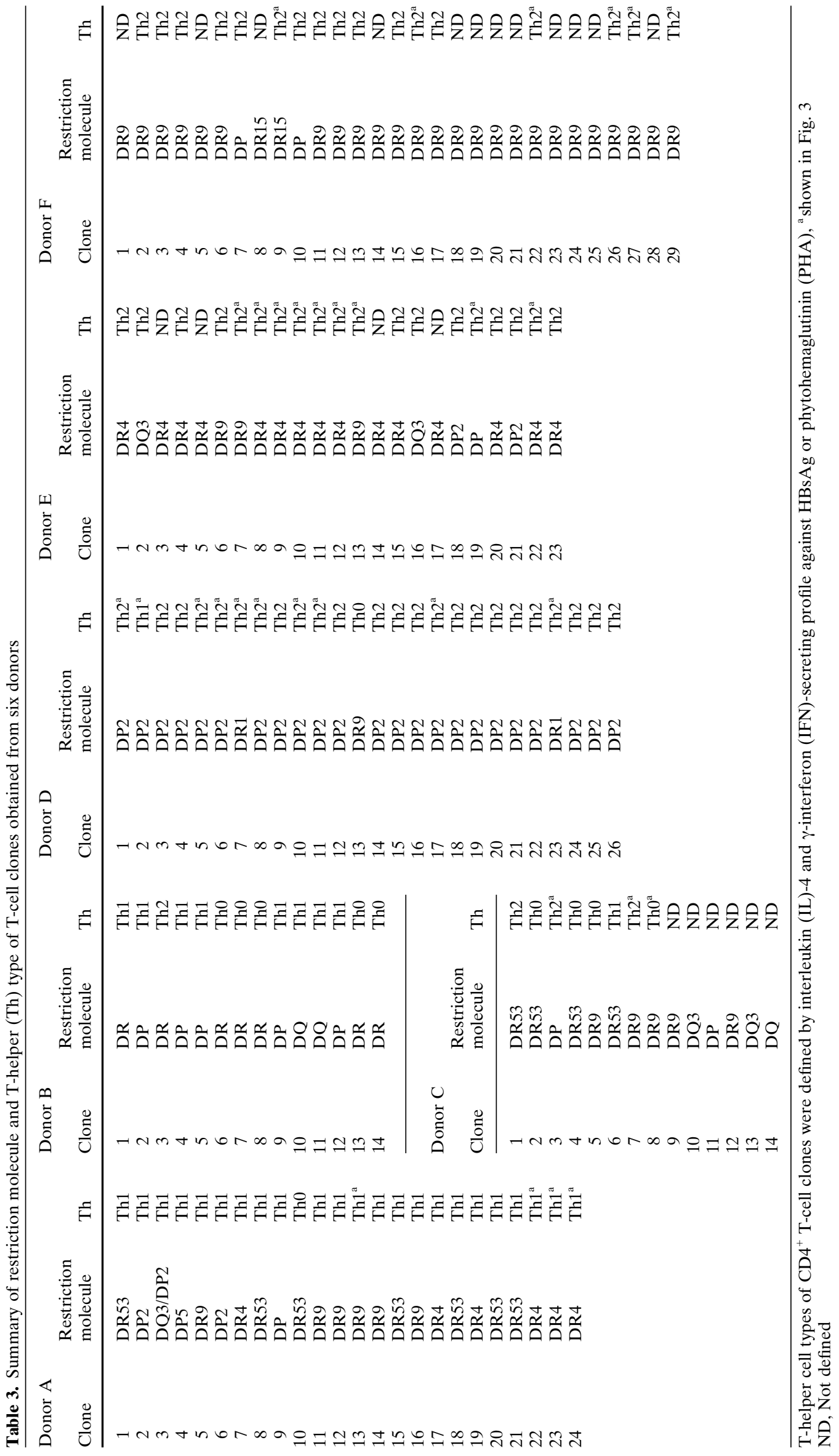


large numbers of T-cell clones specific for HBsAg were analyzed, and it was found that, in vaccinated humans, Th1or Th0-like T cells were predominantly expanded in low$\mathrm{Ab}$ responders, whereas Th2-like $\mathrm{T}$ cells were expanded in high-Ab responders. Therefore, our finding indicates that one of the underlying causes of low responsiveness is the lack of a Th2-like response.

One explanation for the selective activation of a distinct $\mathrm{CD} 4^{+} \mathrm{T}$-cell subset by HBsAg vaccination in humans may be provided by the notion that the HLA class II associated with low- or high-Ab responsiveness presents particular peptide antigens to Th0-type $\mathrm{T}$ cells and induces them to differentiate into Th1- or Th2-like T cells, respectively. Because the sample size in the present study was too small for statistical analysis, this notion should be tested in future experiments in which much larger numbers of low- and high-Ab responders are analyzed.

We previously reported that both HLA class I and HLA class II genes were dynamically involved in Ab production to HBsAg in vaccinated humans (Kruskall et al. 1992; Hatae et al. 1992; Watanabe et al. 1990; Mineta et al. 1996). However, the correlation coefficient for the presence of the entire HLA gene family was assumed to be 0.5 , suggesting that other genetic or environmental factors are involved in the Ab production (Mineta et al. 1996). It has been reported that, in vivo, the priming of Th1 or Th2 cells may be influenced by a number of other factors, including APCs or the cytokine milieu in the lymphoid tissue at the site of inoculation (reviewed in O'Garra and Murphy 1994; Gajewski et al. 1991). In addition, several transcription factors, including T-bet, NFAT, c-Maf, and GATA-3, have been shown to regulate the differentiation of Th0 into Th1/Th2 (reviewed in Glimcher and Murphy 2000). Therefore, polymorphism in these factors may provide an alternative explanation for the selective induction of Th1- and Th2-like cells in low- and high-Ab responders, respectively.

In summary, our data presented here suggest that, in vaccinated humans, low-Ab immune responsiveness to HBsAg is caused, in part, by the predominant induction of a Th1- or Th0-like T-cell response specific for this antigen, resulting in a lack of Th2-like T cells, while high-Ab responsiveness is caused by the predominant induction of Th2-like $\mathrm{T}$ cells. Our finding will provide clues for future investigations to uncover the mechanisms governing immune regulation.

Acknowledegments This work was supported by a grant from CREST, Japan Science and Technology Corporation. We wish to thank Dr H. Wataya for helpful discussion.

\section{References}

Alper CA, Kruskall MS, Marcus-Bagley D, Craven DE, Katz AJ, Brink SJ, Dienstag JL, Awdeh ZL, Yunis EJ (1989) Genetic prediction of nonresponse to hepatitis B vaccine. N Engl J Med 321:708-712

Arthur RP, Mason D (1986) T cells that help B cell responses to soluble antigen are distinguishable from those producing interleukin
2 on mitogenic or allogeneic stimulation. J Exp Med 163:774786

Barnaba V, Franco A, Albert A, Benvenuto R, Balsano F (1990) Selective killing of hepatitis B envelope antigen-specific B cells by class I-restricted, exogeneous antigen-specific $\mathrm{T}$ lymphocytes. Nature 345:258-260

Bocher WO, Herzog-Hauff S, Herr W, Heermann K, Gerken G, Meyer zum Buschenfeld KH, Lohr HF (1996) Regulation of the neutralizing anti-hepatitis B surface (HBs) antibody response in vitro in HBs vaccine recipients and patients with acute or chronic hepatitis $B$ virus (HBV) infection. Clin Exp Immunol 105:52-58

Bocher WO, Herzog-Hauff S, Schlaak J, Meyer zum Buschenfeld KH, Lohr HF (1999) Kinetics of hepatitis B surface antigen-specific immune responses in acute and chronic hepatitis B or after HBs vaccination: stimulation of the in vitro antibody response by interferon gamma. Hepatology 29:238-244

Chiou S-S, Yamauchi K, Nakanishi T, Obata H (1988) Nature of immunological non-responsiveness to hepatitis B vaccine in healthy individuals. Immunology 64:545-550

Date Y, Kimura A, Kato H, Sasazuki T (1996) DNA typing of the HLA-A gene: population study and identification of four new alleles in Japanese. Tissue Antigens 47:93-101

Desombere I, Hauser P, Rossau R, Paradijs J, Leroux-Roels G (1995) Nonresponders to hepatitis B vaccine can present envelope particles to T lymphocytes. J Immunol 154:520-529

Egea E, Iglesias A, Salazear M, Morimoto C, Kruskall MS, Awdeh Z, Schlossman SF, Alper CA, Yunis EJ (1991) The cellular basis of lack of antibody response to hepatitis B vaccine in humans. J Exp Med 173:531-538

Gajewski TF, Pinnas M, Wong T, Fitch FW (1991) Murine Th1 and Th2 clones proliferate optimally in response to distinct antigen-presenting cell populations. J Immunol 146:1750-1758

Glimcher LH, Murphy KM (2000) Lineage commitment in the immune system: the T helper lymphocyte grows up. Genes Dev 14:1693-1711

Hatae K, Kimura A, Okubo R, Watanabe H, Erlich HA, Ueda K, Nishimura Y, Sasazuki T (1992) Genetic control of nonresponsiveness to hepatitis B virus vaccine by an extended HLA haplotype. Eur J Immunol 22:1899-1905

Honorati MC, Dolzani P, Mariani E, Piacentini A, Lisignoli G, Ferrari C, Facchini A (1997) Epitope specificity of Th0/Th2 CD4+ T-lymphocyte clones induced by vaccination with $\mathrm{rHBsAg}$ vaccine. Gastroenterology 112:2017-2027

Hoofnagle GH, Seeff LB, Bales ZB, Wright EC, Zimmerman HJ (1979) Veterans Administration Cooperative Study Group: passiveactive immunity from hepatitis B immune globulin. Reanalysis of a Veterans Administration Cooperative Study of Needle-stick Hepatitis. Ann Intern Med 91:813-818

Hsu HY, Chang MH, Hsieh RP, Ni YH, Chi WK (1996) Humoral and cellular immune responses to hepatitis $\mathrm{B}$ vaccination in hepatitis $\mathrm{B}$ surface antigen-carrier children who cleared serum-hepatitis B surface antigen. Hepatology 24:1355-1360

Itoh Y, Takai E, Ohnuma H, Kitajima K, Tsuda F, Machida A, Mishiro S (1986) A synthetic peptide vaccine involving the product of the pre-S(2) region of hepatitis B virus DNA: protective efficacy in chimpanzees. Proc Natl Acad Sci USA 83:9174-9178

Kimura A, Sasazuki T (1992) Eleventh International Histocompatibility Workshop reference protocol for the HLA DNA typing technique. In: Tsuji K, Aizawa M, Sasazuki T (eds) HLA 1991, vol. 1. Oxford University Press, Oxford, pp 397-419

Kimura A, Dong RP, Harada H, Sasazuki T (1992) DNA typing of HLA class II genes in B-lymphoblastoid cell lines homozygous for HLA. Tissue Antigens 40:5-12

Kruskall MS, Alper CA, Awdeh Z, Yunis EJ (1992) The immune response to hepatitis $B$ vaccine in humans: inheritance patterns in families. J Exp Med 175:495-502

Milich DR, Leroux-Roels G, Louie RE, Chisari FV (1984) Genetic regulation of the immune response to hepatitis $\mathrm{B}$ surface antigen (HBsAg). IV. Distinct H-2 linked Ir genes control antibody response to different $\mathrm{HBsAg}$ determinants on the same molecule and map to the I-A and I-C subregion. J Exp Med 159:41-56

Min WP, Kamikawaji N, Sasazuki T (1996) Identification of an epitope for T-cells correlated with antibody response to hepatitis B surface antigen in vaccinated humans. Hum Immunol 46:93-99

Mineta M, Tanimura M, Tana T, Yssel H, Kashiwagi S, Sasazuki T (1996) Contribution of HLA class I and class II alleles to the regula- 
tion of antibody production to hepatitis B surface antigen in humans. Int Immunol 8:525-531

Mosmann TR, Cherwinski H, Bond MW, Giedlin MA, Coffman RL (1986) Two types of murine helper T cell clone. I. Definition according to profiles of lymphokine activities and secreted proteins. J Immunol 136:2348-2357

Mosmann TR, Coffman RL (1989) TH1 and TH2 cells: different patterns of lymphokine secretion lead to different functional properties. Annu Rev Immunol 7:145-173

O'Garra A, Murphy K (1994) Role of cytokines in determining Tlymphocyte function. Curr Opin Immunol 6:458-466

Paliard X, de Waal Malefijt R, Yssel H, Blanchard D, Chretien I, Abrams J, de Vries J, Spits H (1988) Simultaneous production of IL2, IL-4, and IFN-gamma by activated human CD4+ and CD8+ T cell clones. J Immunol 141:849-855

Paul WE, Seder RA (1994) Lymphocyte responses and cytokines. Cell 76:241-251

Romagnani S (1991) Type $1 \mathrm{~T}$ helper and type $2 \mathrm{~T}$ helper cells: functions, regulation and role in protection and disease. Int $\mathrm{J}$ Clin Lab Res 21:152-158

Szmuness W, Stevens CE, Harley EJ, Zang EA, Oleszko WR, William DC, Sadovsky R, Morrison JM, Kellner A (1980) Hepatitis $B$ vaccine: demonstration of efficacy in a controlled clinical trial in a high-risk population in the United States. N Engl J Med 303: 833-841

Terasaki PI, McClelland JD (1964) Microdroplet assay of human serum cytotoxins. Nature 204:998-1000
Varla-Leftherioti M, Papanicolau M, Spyropoulou M, Vallindara H, Tsiroyianni P, Tassopoulos N, Kapaspuri H, Stavropoulos-Giokas C (1990) HLA-associated nonresponsiveness to hepatitis B vaccine. Tissue Antigens 35:60-63

Vingerhoests J, Vanham G, Kestens L, Penne G, Leroux-Roels G, Gigase P (1994) Deficient T-cell responses in non-responders to hepatitis B vaccination: absence of TH1 cytokine production. Immunol Lett 39:163-168

Wainwright RB, McMahon BJ, Bulkow LR, Hall DB, Fitzgerald MA, Harpster AP, Hadler SC, Lanier AP, Heyward WL (1989) Duration of immunogenicity and efficacy of hepatitis B vaccine in a Yupik Eskimo population. JAMA 261:2362-2366

Watanabe H, Matsusita S, Kamikawaji N, Hirayama K, Okumura M, Sasazuki T (1988) Immune suppression gene on HLA-Bw54-DR4DRw53 haplotype controls nonresponsiveness in humans to hepatitis B surface antigen via CD8+ suppressor T cells. Hum Immunol 22:9-17

Watanabe H, Okumura M, Hirayama K, Sasazuki T (1990) HLABw54-DR4-DRw53-DQw4 haplotype controls nonresponsiveness to hepatitis-B surface antigen via CD8+-positive suppressor $\mathrm{T}$ cells. Tissue Antigens 36:69-74

Wierenga EA, Snoek M, Jansen HM, Bos JD, van Lier RA, Kapsenberg ML (1991) Human atopen-specific types 1 and 2 T helper cell clones. J Immunol 147:2942-2949

Wismans P, van Hattum J, Stelling T, Poel J, de Gast GC (1988) Effect of supplementary vaccination in healthy nonresponders to hepatitis B vaccination. Heptogastroenterology 35:78-79 